\title{
ANALISIS PEMAHAMAN KONSEP MATEMATIKA SISWA DENGAN PENDEKATAN RME KELAS X-IPS SMA SWASTA PEMBDA 1 GUNUNGSITOLI TAHUN PELAJARAN 2017/2018
}

\author{
Netti Kariani Mendrofa \\ Dosen Tetap IKIP Gunungsitoli (Yaperti Nias) \\ netti.mend14@gmail.com
}

\begin{abstract}
Abstrak
Penelitian ini bertujuan untuk mengetahui kemampuan pemahaman konsep siswa pada materi trigonometri dengan menggunakan pendekatan RME. Penelitian ini dilaksanakan pada semester genap tahun ajaran 2017/2018 di Gunungsitoli. Subjek pada penelitian ini adalah siswa kelas X-IPS 1 SMA Swasta Pembda 1 Gunungsitoli dengan jumlah sampel penelitian sebanyak 30 orang siswa. Instrumen penelitian yang digunakan berupa soal tes kemampuan pemahaman konsep dan didukung dengan lembar obsevasi. Data dianalisis dengan menggunakan teknik analisis data kuantitatif deskriptif. Hasil penelitian menunjukkan bahwa pemahaman konsep matematika siswa pada dengan penerapan pendekatan RME memiliki persentase $70,74 \%$ dengan kategori tinggi. Ini berarti, kemampuan pemahaman konsep dengan pendekatan RME menunjukkan hasil yang baik.
\end{abstract}

Kata Kunci: RME, kemampuan pemahaman konsep, tes

\begin{abstract}
This research is aimed to know the ability of understanding mathematical concept of the students of trigonometry with using RME. The research is holding in even semester 2017/2018 in Gunungsitoli. The subject of this research is X-IPS 1 SMA Swasta Pembda 1 Gunungsitoli of sampel are 30 students. Instruments used in this research is a test of understanding of the concept students and supported by observation letter. Analysis data with use analysis technical data kwantitative descriptive. The results showed that the understanding of mathematical concepts students application of RME approaching has precetage $70,74 \%$ with higt category. It means, the ability of understanding mathematical concept with RME approaching is showing good result.
\end{abstract}

Keyword: RME, Understanding Of Mathematical Concepts, Test

\section{PENDAHULUAN}

Matematika merupakan salah satu bagian yang penting dalam bidang ilmu pengetahuan. Untuk dapat memahami suatu pokok bahasan dalam matematika, siswa diharapkan mampu memiliki ke-mampuan matematis yang berguna untuk menghadapi tantangan global. Hal ini senada dengan Permendiknas No. 58 tahun 2014, mata pelajaran matematika salah satunya bertujuan agar siswa memahami konsep matematika, yaitu kompetensi dalam menjelaskan keterkaitan antar-konsep dan menggunakan konsep maupun algoritma, secara luwes, akurat, efisien, dan tepat dalam pemecahan masalah.

Siswa dikatakan berhasil belajar matematika apabila mampu mencapai tujuan matematika yang telah ditetapkan, salah satunya adalah memahami konsep matematika. Pemahaman konsep merupa-kan kemampuan siswa untuk memahami suatu materi pelajaran dengan pembentukan pengetahuannya sendiri dan mampu mengungkapkan kembali dalam bentuk lain yang mudah dimengerti serta mengaplikasikannya. 
Kemampuan pemahaman konsep matematika sangat penting karena dengan memahami konsep siswa akan lebih mudah mempelajari materi yang diterima. Memahami konsep bukan hanya dengan menghafal namun dengan mempelajari contoh-contoh konkret sehingga siswa mampu mendefinisikan sendiri suatu informasi (Hamzah,2006).

Kenyataan yang terjadi di lapangan berdasarkan hasil observasi menunjukan bahwa masih banyak siswa yang belum secara maksimal memahami konsep matematika. Terlihat keaktifan siswa untuk mengembangkan dan menemukan konsep masih rendah. Sebagian siswa hanya menghapal konsep yang diberikan oleh guru, sehingga siswa kesulitan dalam menggunakan operasi/rumus dalam me-nyelesaikan soal. Jika soal latihan sudah berbeda dari contoh soal maka siswa mulai mengalami kesulitan dan terkadang lebih memilih untuk tidak mengerjakan atau berdatangan ke tempat siswa yang pintar untuk melihat contekan. Selain itu terdapat siswa yang mampu menggunakan operasi/ rumus namun masih kesulitan dalam menjelaskan maupun memberikan contoh dari pemahaman konsep yang dipelajari.

Menyikapi hal tersebut perlu adanya solusi agar kemampuan pemahaman konsep siswa dapat maksimal. Salah satu caranya adalah dengan menggunakan pen-dekatan Realistic Mathematics Education (RME). Dalam RME, aktivitas manusia dan matematika harus dihubungkan secara nyata terhadap konteks kehidupan sehari-hari perserta didik sebagai suatu sumber pengembangan dan sebagai area aplikasi melalui proses matematisasi baik hori-zontal maupun vertikal (Zulkardi, 2002). Melalui pendekatan RME, matematika tidak disajikan dalam bentuk hasil jadi rumus atau konsep yang berkaitan dengan materi, tetapi siswa harus mengembang-kan sendiri kemampuan bernalarnya dalam menemukan kembali konsep-konsep matematika tersebut.

Berdasarkan uraian di atas, maka dilakukan penelitian yang diharapkan dapat membantu meningkatkan pemahaman konsep matematika siswa. Penelitian ini bertujuan untuk mengetahui bagaimana kemampuan pemahaman konsep matematika siswa dengan pendekatan RME dalam menyelesaikan soal trigonometri.

\section{METODE PENELITIAN}

Jenis penelitian ini adalah penelitian kuantitatif dengan menggunakan pendekatan deskriptif. Penelitian kuantitatif deskriptif adalah metode penelitian untuk mendapatkan gambaran sistematis mengenai isu suatu dokumen, yaitu ketika dilakukan dengan metode historis dinilai kurang tepat (Surakhmad dalam Andi Prastowo, 2014).

Subjek penelitian adalah kelas XIPS 1 SMAS Pembda 1 Gunungsitoli yang berjumlah 30 orang. Dalam penelitian ini instrumen penelitian yang digunakan adalah tes. Tes ini dirancang untuk melihat kemampuan pemahaman konsep. Soal tes yang diberikan berupa soal essay.

Teknik analisis data dilakukan pada setiap menyelesaikan soal yang kemudian dianalisis menurut indikator pemahaman konsep, yaitu menyatakan ulang konsep, 
mengklasifikasikan objek sesuai dengan konsepnya, memberi contoh dan bukan contoh dari suatu konsep dan menggunakan, memanfaatkan, dan me-milih prosedur atau operasi tertentu dan mengaplikasikan konsep.

Untuk mengetahui tinggi rendahnya persentase pemahaman konsep matematis siswa maka peneliti menggunakan acuan sebagai berikut:

Tabel 1. Presentase Kemampuan Siswa

\begin{tabular}{|c|c|}
\hline Persentase (\%) & Kriteria \\
\hline $0 \leq P<20$ & Sangat rendah \\
\hline $20 \leq P<40$ & Rendah \\
\hline $40 \leq P<60$ & Sedang \\
\hline $60 \leq P<80$ & Tinggi \\
\hline $80 \leq P<100$ & Sangat Tinggi \\
\hline
\end{tabular}

\section{HASIL DAN PEMBAHASAN}

Penelitian diawali dengan menerap-kan pendekatan RME dalam kegiatan pembelajaran. Kemudian dilakukan peng-ujian kemampuan pemahaman konsep siswa dengan pemberian tes berupa soal tes uraian.

Analisis pemahaman konsep yang dilakukan pada siswa kelas XIPS 1 dalam menyelesaikan soal materi trigonometri telah menunjukan hasil. Dari hasil pengerjaan soal yang telah diselesaikan siswa maka diperoleh data kemampuan pemahaman konsep menyelesaikan soal trigonometri ditinjau dari indikator kemampuan pemahaman konsep dan pemecahan masalah matematis yang telah dijelaskan. Untuk lebih jelasnya berikut hasil analisis jawaban siswa terhadap indikator pemahaman konsep.

\section{Tabel 2. Hasil Tes Kemampuan Pemahaman Konsep}

\begin{tabular}{|l|c|c|}
\hline \multicolumn{1}{|c|}{ Indikator } & $\begin{array}{c}\text { Persentase } \\
(\mathbf{\%})\end{array}$ & Kriteria \\
\hline $\begin{array}{l}\text { Menyatakan ulang } \\
\text { konsep }\end{array}$ & 74,56 & Tinggi \\
\hline $\begin{array}{l}\text { Mengklasifikasikan } \\
\text { objek sesuai dengan } \\
\text { konsepnya }\end{array}$ & 74,44 & Tinggi \\
\hline $\begin{array}{l}\text { Memberi contoh dan } \\
\text { bukan contoh dari } \\
\text { suatu konsep }\end{array}$ & 70,55 & Tinggi \\
\hline $\begin{array}{l}\text { Memilih prosedur } \\
\text { atau operasi tertentu }\end{array}$ & 68,42 & Tinggi \\
\hline $\begin{array}{l}\text { Mengaplikasikan } \\
\text { konsep }\end{array}$ & 65,75 & Tinggi \\
\hline \multicolumn{1}{|c|}{ Rata-rata } & 70,74 & Tinggi \\
\hline
\end{tabular}

Berdasarkan tabel 2, terlihat jika hasil persentase siswa kelas X-IPS 1 SMA Swasta Pembda Gunungsitoli dalam menyelesaikan soal trigonometri memiliki persentase $70,74 \%$ dengan kategori tinggi. Hal ini menunjukan jika sebagian besar siswa sudah cukup baik dalam memahami konsep matematika materi trigonometri melalui pendekatan RME. Persentase pemahaman konsep paling tinggi ada pada indikator 1 dan 2 untuk item soal nomor 2 dan 3 yaitu indikator menyatakan ulang konsep dan mengklasifikasikan objek sesuai dengan konsepnya dengan persen-tase jumlah yang hampir sama yaitu sebesar $74,56 \%$ dan 74,44 dengan kategori tinggi. Sedangkan persentase pemahaman konsep matematika paling sedikit ada pada indikator 5 yaitu mengaplikasikan konsep trigonometri sebesar $65,75 \%$ dengan kategori tinggi.

Dari hasil analisis terhadap pemahaman konsep siswa dari setiap indikator, maka indikator menyatakan ulang konsep dan indikator mengklasifikasikan objek sesuai dengan konsepnya menunjukkan jika siswa tidak memiliki permasalahan yang 
berarti dalam me-nyelesaikan soal. Kesalahan hanya terlihat pada proses perhitungan saja. Ini menunjukkan jika konsep siswa sudah baik dengan penerepan pendekatan RME, hanya masih ada beberapa siswa kurang teliti dalam melakukan perhitungan padahal sudah memahami soal dengan baik.

Pada indikator mengklasifikasikan dan memberi contoh bukan contoh trigono-metri berarti siswa menjelaskan kelompok trigonometri serta hubungan antar trigono-metri dalam menyelesaikan soal. Dari hasil analisis juga terlihat siswa tidak mengalami banyak kendala dalam me-nyelesaikan soal. Sebagian siswa sudah mampu memahami dan menalar soal yang diberikan dengan memadukan pada pemahaman konsep trigonometri yang dimiliki. Hanya saja ada beberapa orang siswa yang mengalami kekeliruan. Ber-dasarkan wawancara yang dilakukan kepada siswa, siswa keliru dalam me-mahami soal sehingga soal tersebut tidak dikerjakan.

Pemahaman konsep siswa pada indikator menggunakan, memanfaatkan, dan memilih prosedur atau operasi tertentu dan mengaplikasikan konsep menunjukkan hasil memuaskan. Namun kesalahan terjadi karena siswa bingung menggunakan dan mengaplikasikan konsep yang mana seharusnya digunakan. Ini disebabkan karena siswa kurang memahami soal dengan baik.

Hasil analisis dari indikator kemampuan pemahaman konsep matematis menunjukkan persentase pemahaman konsep siswa secara umum sudah menunjukan hasil yang baik. Penerapan pendekatan RME memiliki dampak yang baik dalam membentuk pemahaman konsep sisiwa. Peran RME dalam mengkonstruksi kemampuan nalar siswa menemukan kembali konsepkonsep pada materi trigonometri telah berjalan. Ini berarti penguasaan siswa pada konsep trigonometri dengan pendekatan RME menunjukkan siswa sudah mampu dengan baik dalam memahami soal, menuliskan pernyataan yang diketahui dalam bentuk matematis dengan baik, dan penyelesaian soal dengan tepat.

\section{KESIMPULAN DAN}

\section{SARAN}

Berdasarkan hasil penelitian terhadap pemahaman konsep matematika siswa dengan menerapkan pendekatan RME menunjukkan jika pemahaman konsep matematika siswa sudah baik. Persentase akumulasi pemahaman konsep menunjukkan jika pendekatan RME di-analisis mampu meningkatkan pemahaman konsep siswa. Siswa mampu menguasai konsep dengan baik, siswa sudah mampu menyelesaikan soal yang diberikan dengan menggunakan memadu-kan konsep yang dimilikinya. Dapat disimpulkan jika, pendekatan RME baik dijadikan sebagai pedoman bagi guru dalam melaksanakan pembelajaran untuk meningkatkan kemampuan penalaran matematis peserta didik.

\section{DAFTAR RUJUKAN}

Andi, Prastowo. 2014. Memahami Metode-Metode Penelitian. Yogyakarta : Ar-Ruzz Media

Arikunto, Suharsimi. (2009). Dasardasar Evaluasi Pendidikan. Jakarta:Bumi Aksara 
Hamzah B Uno. 2006. Orientasi

baru dalam psikologi pembelajaran. Jakarta: PT Bumi Aksara

Gravemeijer, Koeno and Cobb, Paul. 2006. Design research from the Learning Design Perspective. Dalam Jan Ven Den Akker, et. al. Educational Design Research. London: Routledge.

NCTM (2000). Principles and standards for school mathematics. Reston, VA: National Councilof Teachers of Mathematics.

Suherman, Erman, dkk. 2003. Strategi Pembelajaran

Matematika Kontemporer. Bandung: UPI.

Zulkardi. (2002). Developing a Learning Environment on Realistic Mathematics Education for Indonesian Student Teacher. The Netherlands: Twente University. 